\title{
DECAY OF LODGEPOLE PINE IN TWO FOOTHILLS SECTIONS OF THE BOREAL FOREST IN ALBERTA ${ }^{1}$
}

\author{
BY A. A. LOMAN ${ }^{2}$ and G. D. PAUL ${ }^{s}$
}

A. A. Loman was born in Djakarta, Indionesia, in 1931. During World War II he spent 2 years and 9 months in Japanese concentration camps and 6 months in Indonesian prison camps in central Java. In 1951 he completed his secondary schooling in Holland. He obtained his B.S.F. in 1957 at the University of British Columbia, and his M.S. in 1961 at Oregon State University. He has been employed at the Forest Pathology Laboratory, Calgary, since 1957.

G. D. Paul was born in Edmonton, Alberta. He attended Montana State University and received $a$ B.SC.F. in 1957 and an M.SC. in 1959. In 1957 he was employed by the Forest Surveys Branch of Alberta Department of Lands and Forests to conduct a survey of cull losses in Alberta's commercial timber species.

\section{ABSTRACT}

Cull in lodgepole pine (Pinus contorta Dougl. var. latifolia Engelm.) is highly variable in the B19a and B19c Sections of the Boreal Forest in Alberta, depending upon whether the wood is used for pulp or sawed products. Sixtynine per cent of 2,436 sample trees were suspected of containing volumes of red heartwood stain and advanced decay on the basis of the presence of external defects. Fifty-three per cent of the suspects were sound, 36 per cent had red heartwood stain and 11 per cent were partly or entirely decayed. Sixty per cent of the trees without external defects were sound, and 40 per cent had red heartwood stain. In cubic-foot measure decay was unimportant in stands less than 100 years old. In older stands a few infested trees accounted for most of the decay. In foot-board measure 62 of 2,746 sample trees were totally culled and 122 were partially culled. Considerable loss occured in 90-year old and older stands near Whitecourt and in 170-year old stands in the other sample areas. Fomes pini (Thore) Lloyd and Polyporus tomentosus Fr. were the principal fungi isolated from white pitted trunk rots. P. tomentosus and Flammula alnicola $(F r$.$) Kummer were isolated most frequently from white pitted root$ and butt rots, and Coniophora puteana (Schum. ex Fr.) Karst. from brown cubical root and butt rots. Peniophora pseudo-pini Weres. and Gibson was the most frequently isolated fungus but was always associated with red heartwood stain. Scars of all kinds were the most important points of entry for decay fungi.

\footnotetext{
${ }^{1}$ Contribution No. 980, Forest Entomology and Pathology Branch, Department of Forestry, Ottawa, Canada.

${ }^{2}$ Forest Entomology and Pathology Laboratory, Calgary, Alberta.

${ }^{3}$ Formerly with Alberta Department of Lands and Forests, Forest Surveys and Inventory Division, Edmonton, Alberta.
} 


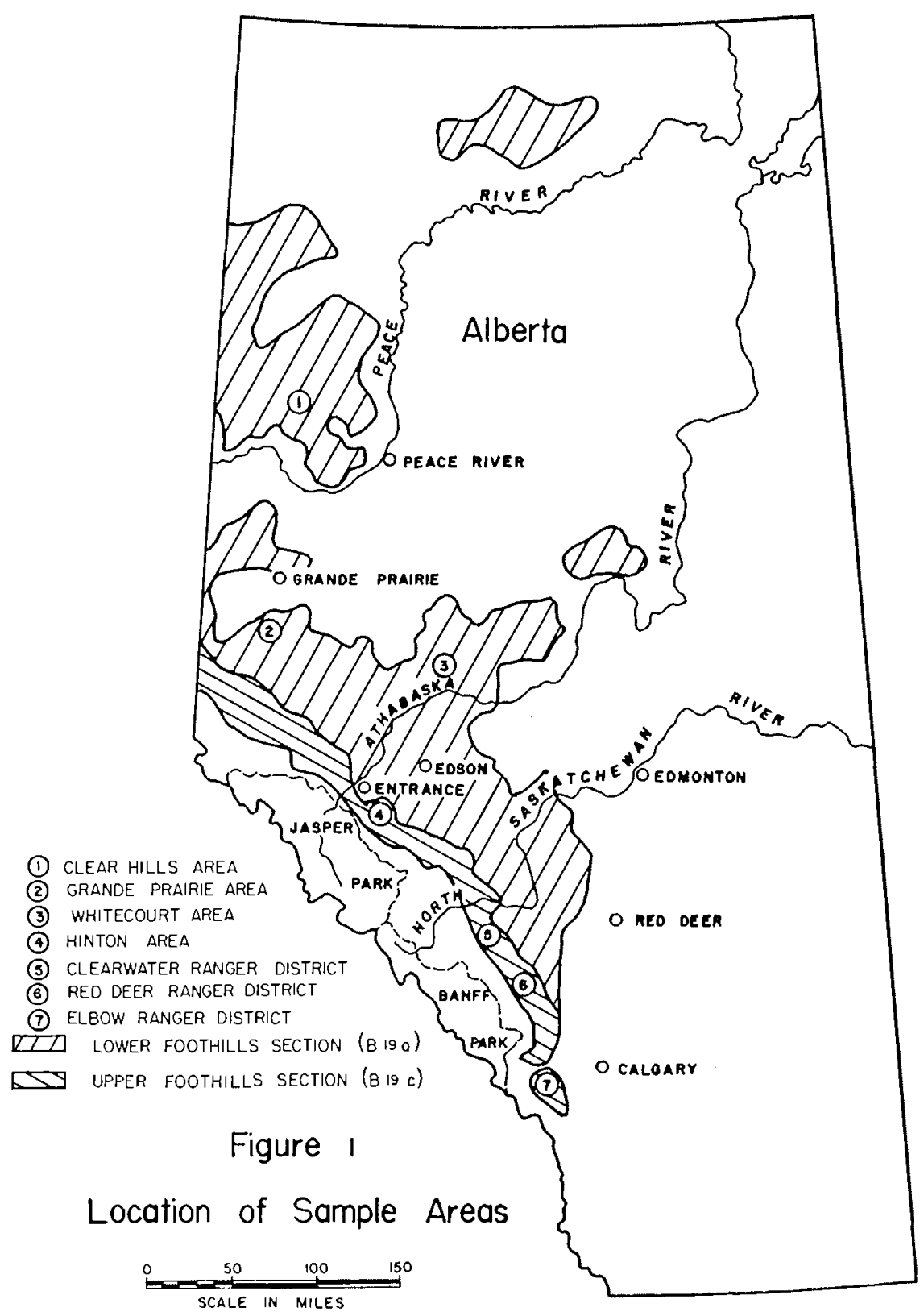




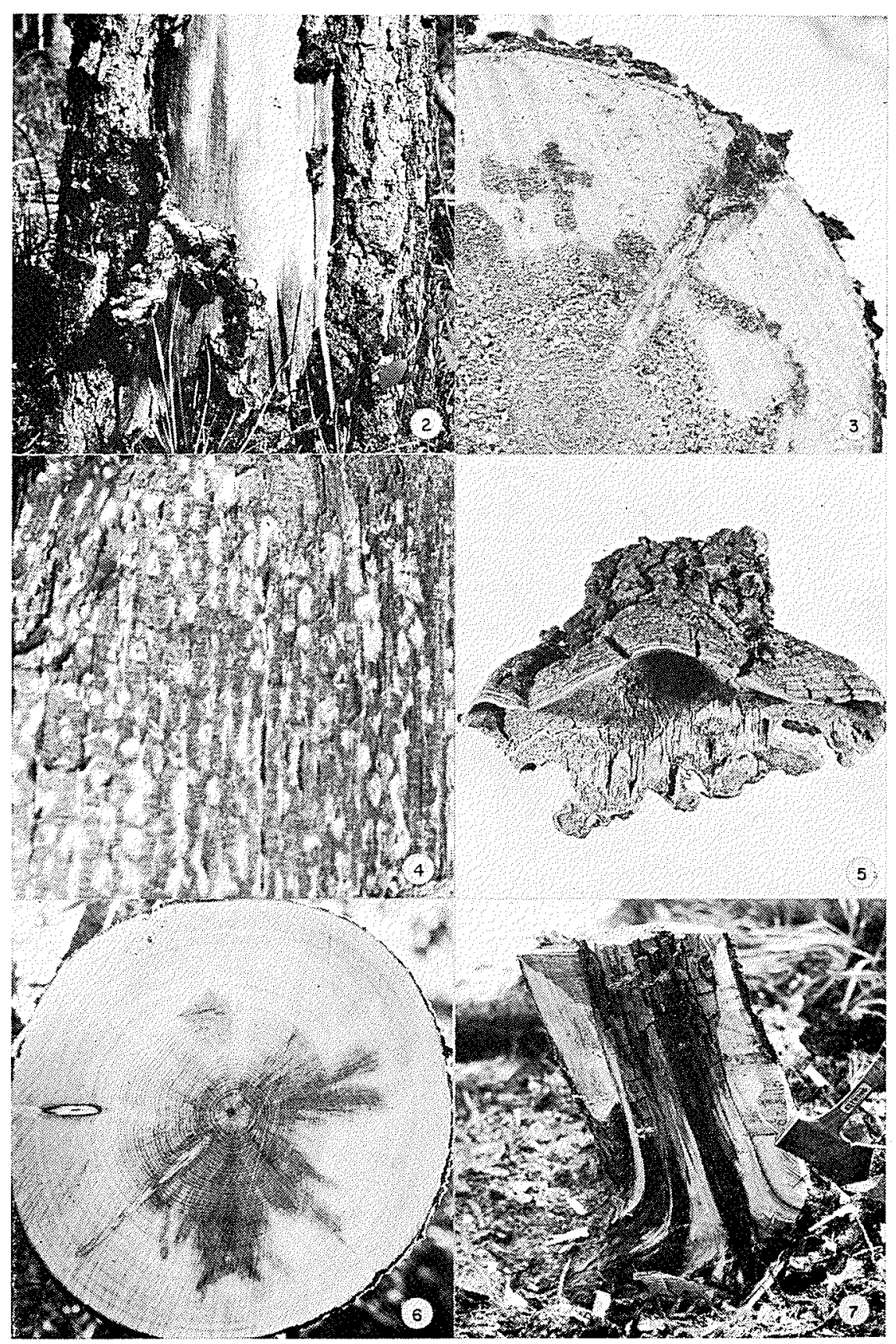


FIGURE 2. Shrinkage cracks on fire scars are the important points of origin for decay in lodgepole pine.

FIGURE 3. Advanced decay of Fomes pini (Thore) Lloyd with a punk knot.

FIGURE 4. Advanced decay of Fomes pint (Thore) Lloyd in radial section.

FIGURE 5. A sporophore of Fomes pini (Thore) Lloyd.

FIGURE 6. Red heartwood stain caused by Peniophora pseudo-pini Weres. and Gibson.

FIGURE 7. Brown cubical decay caused by Coniophora puteana (Schum. ex Fr.) Karst.

\section{INTRODUCTION}

Lodgepole pine is the dominant subclimax species in the Montane and Subalpine Forests and in the Foothills Sections of the Boreal Forest in Alberta (Rowe, 1959). Together with jack pine (Pinus banksiana Lamb.) this species comprises about one quarter of the total provincial inventory of commercial tree species. The average annual cut of pine in Alberta during the period of 1954 to 1959 was about one third of the cut for all species. Its main uses are for lumber, railway ties, pulpwood and round timber.

The identities of the principal fungi isolated from heartwood stains and decays of lodgepole pine in Alberta were established in earlier investigations (Nordin, Sutton and Heming, 1953; Nordin and Carmichael, 1957; and Nordin, 1958). The present study was intended to supply additional information on the decay relationships for the species. In 1960 and 1961 the Alberta Department of Lands and Forests and the Calgary Laboratory of Forest Entomology and Pathology, Canada Department of Forestry, collaborated in this work. Field investigations were limited to the $\mathrm{B} 19 \mathrm{a}$ and $\mathrm{B} 19 \mathrm{c}$ Sections (Rowe, 1959) of the Boreal Forest in Alberta, since most of the commercially important stands of lodgepole pine are found in these areas.

\section{Description of STUdy AREa}

The Lower Foothills Section (B19a) ranges in elevation from 3,000 to 4,000 feet in the south, to approximately 2,500 feet in the north. It resembles Boreal Forest conditions in the prevalence of Mixedwood types. Aspen (Populus tremuloides Michx.) and, to a lesser extent balsam poplar (Populus balsamifera L.) are able to compete with lodgepole pine as post fire pioneers. White spruce (Picea glauca (Moench) Voss var. albertiana (S. Brown) Sarg.) and black spruce (Pincea mariana (Mill.) BSP.) are common. Alpine fir (Abies lasiocarpa (Hook.) Nutt.) is comparatively rare, but may be abundant locally. Average annual precipitation ranges from 16 to 20 inches, with 60 to 70 per cent occurring during the growing season. In the Lower Foothills Section, sample areas were located near Clear Hills, Grande Prairie, and Whitecourt (Fig. 1).

The Upper Foothills Section (B19c) comprises the western part of the transition from Boreal to Subalpine Forest, and ranges in elevation from 4,000 to 6,000 feet. Lodgepole pine, white spruce, and black spruce are the major species. Black spruce occurs sporadically in the southern part of the division, becoming frequent north of the North Saskatchewan River. Alpine fir is less prevalent than in the Subalpine Forest Region, and the poplars are relatively unimportant. Average annual precipitation ranges from 18 to 24 inches, with 60 to 70 per cent occurring during the growing season. In the Upper Foothills Section, sample areas were located near Hinton, and in the Clearwater, Red Deer, and Elbow Ranger Districts. 


\section{Methods}

Eighty-one plots, mostly 0.1 acres in size, were selected in the seven areas with a view to sampling age classes representative of the B19a and B19c Sections. Thirty-nine of the plots were in the Upper Foothills Section and 42 in the Lower Foothills Section.

All pines larger than 3.5 inches in diameter were sampled. The crown position of each tree and the occurrence of potential infection courts such as fire scars, mechanical scars, frost cracks, forks, broken tops and dead leaders, were recorded before felling. Trees having one or more of these features were classified as suspects in terms of their potential for decay.

After felling, the trees were cut into 16-foot sections above a 1 -foot stump until a minimum top-diameter of 3.6 inches was reached. Intermediate cuts were made in an attempt to trace the decay patterns and to locate the entry points of each of the decays. The decays were described in their fresh condition, and samples were sent to the laboratory for identification of the associated fungi. The distribution and frequency of the fungi that were isolated have been reported earlier (Robinson-Jeffrey and Loman, 1963).

The gross volume of each tree was calculated in cubic feet (Smalian's formula $)^{4}$ as the sum of 16 -foot logs and top logs to a minimum diameter of 3.6 inches. Individual volumes of rot were measured and were totalled for each tree. Gross tree volumes were also calculated in board feet (International 5/16-inch $\log$ rule). A one-inch trim allowance was added to decay diameter in calculating net volumes in board feet. Logs with more than 66 per cent of their contents classified as cull were considered to be total culls. There was no trim allowance made in calculating cubic-foot rot volumes, and logs were not culled because of excessive amounts of rot. Cull was calculated in foot-board measure to include heartrot, advanced red heartwood stain, and natural defects such as forks, crook, sweep, and cracks. The relative amounts of heartrot and red heartwood stain were considered separately in estimating losses on a cubic foot basis. Defects other than stain and decay were not included in cubic-foot analyses.

$$
\begin{aligned}
& \text { "Smalian's formula: cubic feet volume }=\frac{(\mathrm{B}+\mathrm{b})}{2} . \text { when } \\
& \qquad \begin{array}{l}
\mathrm{B}=\text { area of base, sq. } \mathrm{ft} . \\
\mathrm{b}=\text { area of top, sq. } \mathrm{ft} . \\
\mathrm{h}=\text { height in feet }
\end{array}
\end{aligned}
$$

Tree age was calculated as the sum of the stump age and the age of seedlings of stump height. When stump rot prevented age counts, trees were considered to be the same age as those of comparable size and growth pattern for which actual counts could be made. In the board foot measure analysis, stands were grouped in 20-year age classes on the basis of the average age of dominant and codominant trees. In the cubic foot scale analysis individual trees were grouped in 20-year age classes on the basis of their actual age.

\section{BASIC DATA}

Board-foot basis of measurement

Basic data in board-foot measure are summarized in Table 1. A total of 


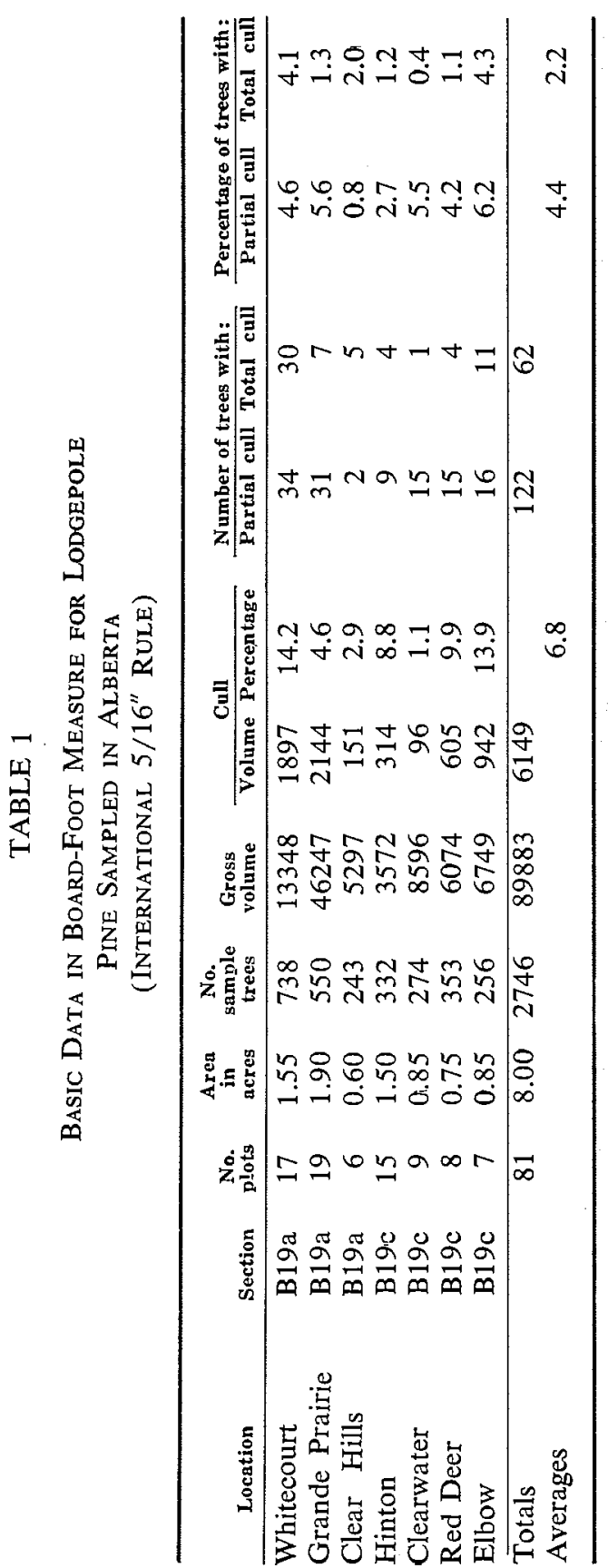


2,746 trees were examined in the 81 plots, 62 were totally culled and 122 were partially culled. The cull percentages expressed in Table 1 were based on total gross and cull volumes of all age classses for each of the sample areas. In the lower Foothills Section cull ranged from 2.9 to 14.2 per cent, in the Upper Foothills Section from 1.1 to 13.9 per cent. With the exception of the Whitecourt area, where relatively high amounts of cull were found in 90-year old stands, high cull percentages were found only in stands older than 170 years.

Cubic-foot basis of measurement

Basic data in cubic feet are summarized in Table 2. A total of 2,436 trees were analyzed for 61 of the 81 plots. Data for the 15 plots at Hinton and 5 of the plots at Clearwater were not amenable to cubic-foot analyses and were therefore excluded. Stain and decay volumes were generally low in all of the 61 plots. An average of 4.3 per cent of the volume of all sampie trees had red heartwood stain, and 2.0 per cent had heartrot.

\section{Cull in relation to tree age (board-foot basis)}

CUll Relationships

Age-cull relationships are summarized in Table 3 for the seven sample areas. With the exception of Whitecourt, cull was of little consequence in stands less than 100 years old. In this area 15.3 per cent of the gross volume was culled in 90-year old stands. Sixty-five per cent of the cull volume in this age class occurred in 8 totally culled trees. In 130-year old stands at Whitecourt most of the cull occurred in partially culled trees, and very few trees were totally culled.

At Grande Prairie 4.6 per cent of the volume of 150 -year old stands was culled, about one-quarter of which was contained in a single tree. About 10 per cent of the volume of 170-year old stands at Grande Prairie was culled. Cull was unimportant in the Clear Hills area. Cull was of little consequence in stands of up to 130 years at Hinton, but in a 170-year old stand it amounted to 15.0 per cent with 2 trees contributing 82 per cent of the cull volume. Cull was highly variable in stands older than 170 years at Hinton, and again a very few trees contributed to most of the cull. At Red Deer cull was important only in stands older than 240 years. In the Elbow Ranger District cull was greater in slightly younger stands, amounting to 17.5 per cent in 190-year old stands and 16.1 per cent in 230-year old stands.

\section{Decay in relation to tree age (cubic-foot basis)}

The age-decay relationships in cubic foot measure summarized in Table 4 demonstrate the relatively small stain and decay volumes that can be expected in lodgepole pine in Alberta. The present results confirm earlier low estimates for Alberta (Nordin, 1958), and correspond to similarly low decay losses for jack pine in Ontario (Basham, 1958).

A considerable proportion of the advanced decay occurred in only a very few trees. For example, at Grande Prairie two of the 16 trees with decay accounted for 56 per cent of the total decay volume in 150-year old stands. In the next older age class in the same area one of the 6 trees with advanced decay accounted for 64 per cent of the total decay volume. 


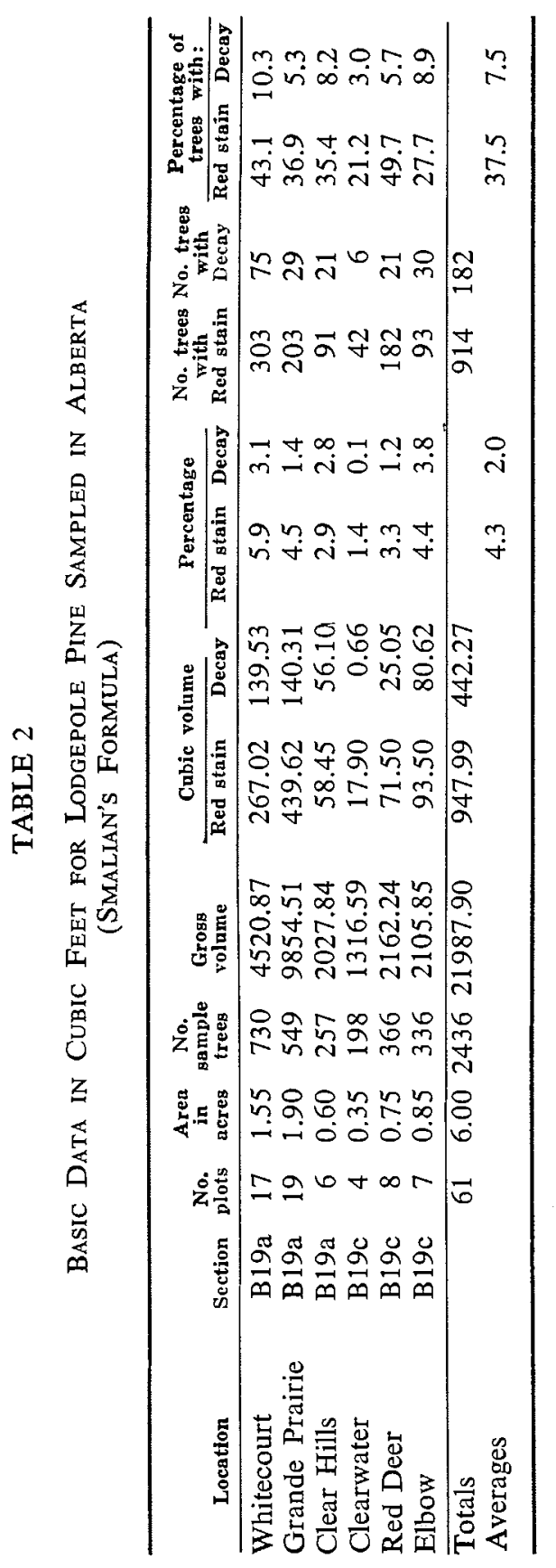


TABLE 3

Age-Cull Relationships in Foot-Board Measure For Lodgepole Pine IN ALBERTA?

(INTERnational 5/16" Rule)

\begin{tabular}{|c|c|c|c|c|c|}
\hline \multirow[b]{2}{*}{ Location } & \multirow[b]{2}{*}{ Age class } & \multirow[b]{2}{*}{ No. trees } & \multicolumn{2}{|c|}{ Number of trees: } & \multirow{2}{*}{$\begin{array}{l}\text { Percentage } \\
\text { of volume } \\
\text { culled }\end{array}$} \\
\hline & & & $\begin{array}{c}\text { Partially } \\
\text { culled }\end{array}$ & $\begin{array}{l}\text { Totally } \\
\text { culled }\end{array}$ & \\
\hline \multicolumn{6}{|l|}{ Whitecourt } \\
\hline \multirow[t]{3}{*}{ (B19a) } & $61-80$ & 351 & 0 & 0 & 0 \\
\hline & $81-100$ & 117 & 3 & 8 & 15.3 \\
\hline & $121-140$ & 270 & 31 & 22 & 17.4 \\
\hline \multicolumn{6}{|c|}{ Grande Prairie } \\
\hline \multirow[t]{5}{*}{$(\mathrm{B} 19 \mathrm{a})$} & $61-80$ & 246 & 0 & 0 & 0 \\
\hline & $101-120$ & 54 & 2 & 1 & 2.3 \\
\hline & $121-140$ & 14 & 2 & 0 & 1.3 \\
\hline & $141-160$ & 164 & 20 & $1^{2}$ & 4.6 \\
\hline & $161-180$ & 72 & 7 & 5 & 9.8 \\
\hline \multicolumn{6}{|l|}{ Clear Hills } \\
\hline \multirow[t]{2}{*}{ (B19a) } & $61-80$ & 59 & 0 & 0 & 0 \\
\hline & $101-120$ & 184 & 2 & 5 & 3.2 \\
\hline \multicolumn{6}{|l|}{ Hinton } \\
\hline \multirow[t]{9}{*}{ (B19c) } & $61-80$ & 131 & 0 & 0 & 0 \\
\hline & $81-100$ & 96 & 0 & 0 & 0 \\
\hline & $101-120$ & 11 & 1 & 0 & 2.8 \\
\hline & $121-140$ & 18 & 0 & 0 & 0 \\
\hline & $161-180$ & 24 & 3 & $2^{3}$ & 15.0 \\
\hline & $181-200$ & 22 & 1 & 0 & 2.5 \\
\hline & $201-220$ & 14 & 2 & 0 & 2.9 \\
\hline & $221-240$ & 7 & 1 & 1 & 19.7 \\
\hline & $281-300$ & 9 & 1 & 1 & 36.7 \\
\hline \multicolumn{6}{|l|}{ Clearwater } \\
\hline \multirow[t]{3}{*}{ (B19c) } & $61-80$ & 207 & 10 & 1 & 1.3 \\
\hline & $81-100$ & 39 & 0 & 0 & 0 \\
\hline & $121-140$ & 28 & 5 & 0 & 2.0 \\
\hline \multicolumn{6}{|l|}{ Red Deer } \\
\hline \multirow[t]{4}{*}{$(B 19 c)$} & $61-80$ & 99 & 0 & 0 & 0 \\
\hline & $81-100$ & 59 & 0 & 0 & 0 \\
\hline & $101-120$ & 161 & 0 & $a$ & 0 \\
\hline & $241-260$ & 34 & 15 & 4 & 17.8 \\
\hline \multicolumn{6}{|l|}{ Elbow } \\
\hline \multirow[t]{4}{*}{ (B19c) } & $61-80$ & 34 & 1 & 0 & 0.2 \\
\hline & $81-100$ & 123 & 2 & 0 & 0.4 \\
\hline & $181-200$ & 26 & 6 & 3 & 17.5 \\
\hline & $221-240$ & 73 & 7 & 8 & 16.1 \\
\hline
\end{tabular}

${ }^{1}$ Actual values are quoted.

This tree contained 23 per cent of the cull volume in this age class.

${ }^{3}$ These two trees contained 82 per cent of the cull volume in this age class. 
About 5 per cent of the volume of the 110- and 130-year old stands at Whitecourt was decayed. Similar small losses were experienced in 230- and 250-year old stands in the Red Deer Ranger District. In the Elbow Ranger District, 5.9 and 7.5 per cent of the volume of 190 - and 230-year old stands were decayed. Decay losses amounted to less than 5 per cent in all other age classes everywhere in the sample area.

Entrance and establishment of decay

Most of the decay had originated in the vicinity of cracks in the exposed wood of fire scars (Fig. 2). The importance of fire scars as points of origin for decay is demonstrated in Table 5 .

Sixteen hundred and seventy-eight of 2,436 sample trees had potential infection courts for decay fungi and 182 (11 per cent) of these were actually decayed. Only two trees were decayed that did not have any external indication of the possibility of their being decayed.

Fire scars occurred on 1,173 trees and were 10 per cent effective as decay indicators. Mechanical scars occurred on 266 trees and were 11 per cent indicative of decay. Other less common abnormalities were, decayed branch stubs (100 per cent indicative), false leaders and forks (4 per cent indicative) and frost cracks (40 per cent indicative). Broken tops of living trees had no cull indicator value.

Recent investigations of the heart-rotting fungus Stereum sanguinolentum (Alb. and Schw. ex Fr.) Fr. in eastern Canada (Davidson and Etheridge, 1963) showed that this fungus becomes established in balsam fir (Abies balsamea (L.) Mill.) only as a result of injuries to living stems and branches. In the present study there was no evidence that branch injuries are focal points for the establishment of decay fungi in lodgepole pine. Similarly, dead branches were unlikely points of entry for decay fungi. Twenty-one trees had advanced decay in embedded branches, but this decay seemed to be an outward extension of stem decay and had sometimes terminated at the stem surface as characteristic punk knots (Fig. 3). Small pockets of either stain or decay occurred in the embedded portions of dead branches in some of the trees that did not have stem decay. In these instances the stained and decayed tissues had been isolated from surrounding stem tissues by a resin barrier.

Seven hundred and fifty-eight of 2,436 sample trees had no signs or symptoms of stain or decay and were therefore called "residuals". Forty per cent of these residuals contained red stain. Even careful dissections of the infected residuals did not reveal entrance courts for the red stain fungi.

\section{The principal decay fungi}

Formes pini (Thore) Lloyd was frequently and consistently isolated from a white pitted trunk rot, either in pure culture or in mixture with Polyporus tomentosus Fr. Based on high incidence, and in view of the very small number of isolations of other fungi from white pitted rot, Fomes pini is without doubt the most important trunk decaying organism in lodgeple pine (Fig. 4). Its fruit bodies are perennial and highly variable in size and shape (Fig. 5). They develop on all species of dead and living conifers that occur in association with lodgepole pine. Peniophora pseudo-pini Weres. and Gibson was associated exclusively with red heartwood stain (Fig. 6). 
TABLE 4

Age-Decay Relationships in Cubic-Foot Measure For Lodgepole Pine in Alberta 1

(SMALIAN's FormUla)

\begin{tabular}{|c|c|c|c|c|c|c|}
\hline \multirow{2}{*}{ Location } & \multirow{2}{*}{ Age class } & \multirow{2}{*}{ No, trees } & \multirow{2}{*}{$\frac{\text { No. trees }}{\text { Red stain }}$} & \multirow{2}{*}{$\frac{\text { with: }}{\text { Decay }}$} & \multicolumn{2}{|c|}{$\begin{array}{l}\text { Percentage of volur } \\
\text { culled because of }\end{array}$} \\
\hline & & & & & Red stain & Deca \\
\hline \multicolumn{7}{|c|}{ Whitecourt } \\
\hline \multirow[t]{5}{*}{ (B19a) } & $41-60$ & 46 & 14 & 0 & 13.7 & 0 \\
\hline & $61-80$ & 303 & 81 & 0 & 5.8 & 0 \\
\hline & $81-100$ & 113 & 55 & 8 & 5.1 & 0 . \\
\hline & $101-120$ & 120 & 68 & 28 & 4.9 & \\
\hline & $121-140$ & 148 & 85 & 39 & 6.3 & \\
\hline
\end{tabular}

Grande Prairie

$\begin{array}{rrrcll}41-60 & 34 & 8 & 1 & 3.9 & 0.8 \\ 61-80 & 214 & 42 & 0 & 0.8 & 0 \\ 81-100 & 11 & 9 & 0 & 7.0 & 0 \\ 101-120 & 53 & 19 & 3 & 1.7 & 0.8 \\ 121-140 & 58 & 30 & 3 & 6.1 & 0.2 \\ 141-160 & 135 & 70 & 16^{2} & 5.6 & 2.2 \\ 161-180 & 44 & 25 & 6^{3} & 3.0 & 2.4\end{array}$

Clear Hills

(B19a)

$\begin{array}{rrrrll}41-60 & 4 & 0 & 0 & 0 & 0 \\ 61-80 & 55 & 5 & 0 & 0.8 & 0 \\ 81-100 & 3 & 1 & 0 & 0.1 & 0 \\ 101-120 & 195 & 85 & 21 & 3.4 & 3.3\end{array}$

Clearwater (B19c)

$\begin{array}{rrrlll}41-60 & 1 & 1 & 0 & 0.1 & 0 \\ 61-80 & 132 & 14 & 1 & 0.5 & T^{4} \\ 81-100 & 38 & 15 & 0 & 0.6 & 0 \\ 101-120 & 4 & 2 & 0 & 9.8 & 0 \\ 121-140 & 23 & 10 & 5 & 2.9 & 0.2\end{array}$

Red Deer (B.19c)

$\begin{array}{rrrrll}41-60 & 17 & 3 & 0 & 0.2 & 0 \\ 61-80 & 96 & 45 & 0 & 2.7 & 0 \\ 81-100 & 74 & 41 & 0 & 4.2 & 0 \\ 101-120 & 144 & 78 & 1 & 3.9 & \mathrm{~T} \\ 121-140 & 1 & 1 & 0 & 8.6 & 0 \\ 201-220 & 3 & 2 & 1 & 3.2 & \mathrm{~T} \\ 221-240 & 8 & 4 & 4 & 8.3 & 4.5 \\ 241-260 & 16 & 5 & 11 & 1.3 & 5.3 \\ 261-280 & 7 & 3 & 4 & 1.6 & 0.3\end{array}$


DECEMBER, 1963

Elbow

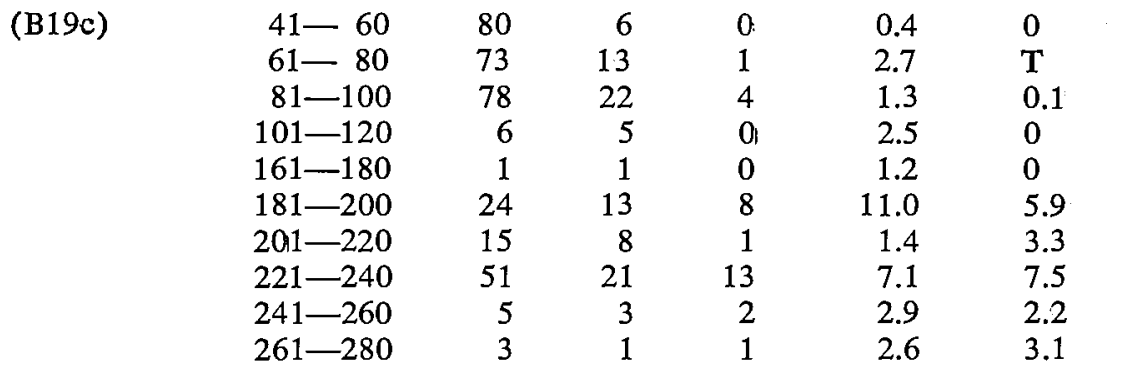

${ }^{1}$ Actual values are quoted.

32 of these 16 trees contained 56 per cent of the total decay volume in this age class.

${ }^{3} 1$ of these 6 trees contained 64 per cent of the total decay volume in this age class.

${ }^{1} \mathrm{~T}$ Trace, less than 0.1 per cent.

TABLE 5

The Number of Suspects and the Percentage Reliance of Individual Defects as Indicators of Advanced Decay and Red Heartwood Stain in Lodgepole Pine in Alberta

\begin{tabular}{|c|c|c|c|c|c|c|}
\hline \multirow[b]{2}{*}{ Defects } & \multicolumn{2}{|c|}{ Advanced Decay ${ }^{1}$} & \multicolumn{2}{|c|}{ Red Stain ${ }^{2}$} & \multicolumn{2}{|c|}{ Sound $^{3}$} \\
\hline & $\begin{array}{c}\text { No. of } \\
\text { Suspects }\end{array}$ & Reliance & $\begin{array}{c}\text { No. of } \\
\text { Suspects }\end{array}$ & Reliance & $\begin{array}{c}\text { No. of } \\
\text { Suspects }\end{array}$ & Reliance \\
\hline Fire scars & 120 & $10 \%$ & 432 & $37 \%$ & 621 & $53 \%$ \\
\hline Mechanical scars & 29 & $11 \%$ & 104 & $39 \%$ & 133 & $50 \%$ \\
\hline Decayed branch stubs & 21 & $100 \%$ & - & $0 \%$ & 一 & $0 \%$ \\
\hline False leaders and forks & 4 & $4 \%$ & 31 & $32 \%$ & 62 & $64 \%$ \\
\hline Broken tops & - & $0 \%$ & 24 & $31 \%$ & 53 & $69 \%$ \\
\hline Frost cracks & 4 & $40 \%$ & 6 & $60 \%$ & - & $0 \%$ \\
\hline Miscellaneous & 4 & $12 \%$ & 12 & $35 \%$ & 18 & $53 \%$ \\
\hline
\end{tabular}

${ }^{1}$ Basis 182 trees $=11$ per cent of all suspects.

${ }^{2}$ Basis 609 trees $=36$ per cent of all suspects.

${ }^{3}$ Basis 887 trees $=53$ per cent of all suspects. 
The principal root and butt decay organisms were Polyporus tomentosus Fr. and Flammula alnicola (Fr.) Kummer, both isolated from white pitted root and butt rots, and Coniophora puteana (Schum. ex Fr.) Karst. which was isolated from a brown cubical root and butt rot (Fig. 7).

\section{Discussion}

Most lodgepole pine stands in Alberta have originated from fires. The maximum age range within individual stands is about 20 years, occasionally up to 40 years (Smithers, 1961). Variable densities in young even-aged stands are common and often result from uneven seed supplies following fires. Extensive fires may establish even-aged forests on a great variety of soil types and topographies that are differentially suited to growing pine. Among the more serious disturbances with pathological consequences that may occur in the life of a pine stand are ground fires, which in themselves are highly variable in extent and intensity. The total complex of factors that enter into the establishment and growth of lodgepole pine has made it very difficult to develop a site classification system that takes into adequate consideration the biological factors involved. The lack of a suitable site classification system prevented the determination of all but the most elementary decay relationships in the present study. Within these limitations, lodgepole pine is clearly a species with little advanced decay. No advanced decay was found in stands less than 100 years old. Considerable amounts of decay commenced at about the 161-180 year age class, but most of the decay was confined to a very few trees.

The large differences between estimates of total cull (footboard measure) and losses resulting from decay and stain only (cubic-foot measure) emphasize the propriety of considering the intended use of lodgepole pine before cull estimates are made. For example, less than one per cent of the gross cubic-foot volume of 90-year old stands at Whitecourt was decayed, but when the same stands were evaluated in terms of board feet the volume loss was 15.3 per cent. Two hundred and fifty-year old stands in the Red Deer Ranger District were only 5.3 per cent decayed, but the total cull in board feet in the same stands was 17.8 per cent. When pine is to be converted to pulp, the lower estimates will be more meaningful than the higher estimates. When either lumber or plywood is the intended use for pine, the higher cull estimates will apply.

Sixty-nine per cent of the total sample of trees were initially suspected of being decayed, because of the presence of one or other visible abnormality of presumed decay significance. However 53 per cent of these were sound, 36 per cent contained red heartwood stain, and only 11 per cent were either partly or entirely decayed. While more than 98 per cent of all the trees that were decayed had been classified as suspects, it is clear that the development of a cull indicator system for estimating heartrot in lodgepole pine is impractical. The reason for this is that the occurrence of measurable amounts of heartrot in lodgepole pine in Alberta is extremely variable, and also that most of the decay occurs in a very few trees that are indistinguishable from trees that are not seriously decayed. The application of simple cull factors is therefore recommended for estimating heartrot in lodgepole pine. 
When the cubic-foot measure is employed no allowance need be made for heartrot in trees up to 100 years. Above 100 years the amount of heartrot will vary appreciably between areas (Table IV), but should seldom exceed more than 5 per cent of the gross volume of trees up to 170 years and 8 per cent of trees older than 170 years. When the board-foot measure is employed, i.e. when other defects in addition to heartrot are being considered, not more than 2 per cent allowance need be made in stands with an average age of up to 100 years. Not more than 5 per cent need be allowed for stands up to 150 years and 20 per cent for stands more than 150 years. In the Whitecourt area, 15 to 18 per cent allowance is required for stands older than 80 years.

\section{ACKNOWLEDGEMENTS}

The authors wish to thank members of the forestry staff of North Western Pulp and Power Ltd., Hinton, Alberta who materially assisted the work done near Hinton. Senior officers of the Alberta Forest Service contributed in many ways to the work through their active support of the project. Thanks are due to Mr. P. S. Debnam for the preparation of the photographs.

\section{REFERENCES}

BASHAM, J. T. 1958. Forest Resources Inventory, Cull Studies. Division of Timber. Ontario Department of Lands and Forests, Report No. 25. 96 pp.

DAVIDSON, A. G., and D. E. ETI-IERIDGE. 1963. Infection of balsam fir, Abies balsamea (L.) Mill, by Sterenm sanguinolentum (Alb. and Schw. ex Fr.) Fr. Can. J. Bot. 41(6): 759-765.

NORDIN, V. J., WILMA SUTTON and J. W. HEMING. 1953. Red stain and decay of lodgepole pine in Alberta. Can. Dept. Agric., For. Biol. Div., Bi-Monthly Prog. Rept. $9(3): 4$.

NORDIN, V. J., and E. . CARMICHAEL. 1957. Red stain in lodgepole pine. Can. Dept. Agric., For. Biol. Div., Bi-Monthly Prog. Rept. 13(1): 3.

NORDIN, V. J. 1958. Basal fire scars and the occurrence of decay in lodgepole pine. For. Chron. 34: 257-265.

ROBINSON-JEFFREY, R.C. and A. A. LOMAN. 1963. Fungi isolated in culture from red heartwood stain and advanced decay of lodgepole pine in Alberta. Can. J. Bot. 41(9): $1371-1375$.

ROWE, J. S. 1959. Forest Regions of Canada. Canada Department of Northern Affairs and National Resources, Forestry Branch, Bull. 123. 71 pp.

SMITHERS, L. A. 1961. Lodgepole pine in Alberta. Can. Dept. Forestry, Bull. No. 127. 153 pp. 